\title{
Are antioxidant capacity and oxidative damage related to biological and autecological characteristics in aquatic insects?
}

\author{
Ana SANZ, ${ }^{1}$ Manuel J. LÓPEZ-RODRÍGUEZ, ${ }^{2}$ Sergio GARCÍA-MESA, ${ }^{1}$ Cristina E. TRENZADO,${ }^{3}$ Rosa M. FERRER, ${ }^{3}$ \\ J. Manuel TIERNO DE FIGUEROA, ${ }^{1 *}$
}

${ }^{1}$ Departamento de Zoología, Facultad de Ciencias, Universidad de Granada, Campus Fuentenueva s/n, 18071 Granada; ${ }^{2}$ Departamento de Ecología, Facultad de Ciencias, Universidad de Granada, Campus Fuentenueva s/n, 18071 Granada; ${ }^{3}$ Departamento de Biología Celular, Facultad de Ciencias, Universidad de Granada, Campus Fuentenueva s/n, 18071 Granada, Spain

*Corresponding author: J. Manuel Tierno de Figueroa, Departamento de Zoología, Facultad de Ciencias, Universidad de Granada, Campus Fuentenueva s/n, 18071, Granada, Spain. Tel. +34.958.241000 ext: 20099. E-mail: jmtdef@ugr.es

\begin{abstract}
In this work, we study the oxidative state of nine taxa of aquatic insects [Serratella ignita (Poda, 1761), Ephemera danica Müller, 1764, Crocothemis erythraea (Brullé, 1832), Dinocras cephalotes (Curtis, 1827), Perla bipunctata Pictet, 1833, Isoperla morenica Tierno de Figueroa \& Luzón-Ortega, 2011, Notonecta maculata Fabricius, 1794, Gerris sp., and Hydropsyche sp.] in order to determine the relationships between this state and the biological and environmental characteristics of the species studied. The studied taxa are all in the same life cycle stage (nymph/larva), and many of them have different maximum life span potentials. We assess the antioxidant capacity through the determination of the trolox-equivalent antioxidant capacity, the ferric-reducing/antioxidant power and the activity of the antioxidant enzymes catalase, DT-diaphorase, glutathione peroxidase, glutathione reductase, glutathione transferase, superoxide dismutase and glucose-6-phosphate dehydrogenase. Furthermore, to determine the oxidative damage, we examine thiobarbituric acid reactive substances, free malondialdehyde, protein-bound malondialdehyde, total hydroperoxides, and protein hydroperoxides. In summary, we can consider that having predatory feeding habits, having a long-life cycle and living in permanent streams with cold, well-oxygenated waters are related to a proper oxidative state in the insects that we studied. On the other hand, non-exclusive predator species living in temporary streams with warm and poorly oxygenated waters with a short life cycle have a worse oxidative state. Thus, the oxidative state of each taxa could be defined by an interaction of biological and autecological factors, for which the relative importance is difficult to assess.
\end{abstract}

Key words: Antioxidant enzymes; feeding habits; freshwater insects; habitat; life cycle; oxidative state.

Received: September 2016. Accepted: October 2016.

\section{INTRODUCTION}

Ageing is a physiological process under a clear genetic regulation that happens, continuously and progressively, from birth to death of the organisms. This manifests in a set of molecular, genetic, cellular, tissular and organic alterations that affect the morphology, physiology and behaviour of organisms. The theory of ageing by free radicals of mitochondrial origin (Harman, 1956; Hulbert et al., 2007) is the most accepted theory for explaining the characteristics of ageing because mitochondria are an endogenous source of free radicals and all the cells forming the vital organs produce those radicals continuously in them. The production of reactive oxygen species (ROS) in isolated mitochondria of post-mitotic tissues is lower in long-lived animal species than in short-lived species (Ku et al., 1993; Barja, 2004; Dowling and Simmons, 2009; Monaghan et al., 2009). On the other hand, when the maximum life span potential (MLSP) of a species is greater, the intensity of the oxidative attack to its mito- chondrial DNA is lower (Richter et al., 1988; Barja, 2000; Barja and Herrero, 2000). Oxidative stress occurs when organisms have an imbalance between pro-oxidant and anti-oxidant molecules. Pro-oxidant molecules (free-radical oxygen species and other reactive species) trigger a cascade-like process, producing lipid hydroperoxides $(\mathrm{LOOH})$ and protein hydroperoxides $(\mathrm{PrOOH})$ and damaging biological membranes and other lipid- and proteincontaining structures (Halliwell, 2007).

The majority of the studies about animal longevity that were initially conducted focused on antioxidant factors. One of the first hypotheses raised was that ageing could occur due to a decrease in antioxidant levels. Several studies have noted a lack of a uniform pattern in the variation of the cellular antioxidant concentrations with either individual age or the MLSP of a given species, and the results that were obtained depended on the antioxidant measured, the studied organ or the chosen species (Tolmasoff et al., 1980; Sohal et al., 1990; Mockett et al., 1999; Huang et al., 2000). In a study of two species of fish [rainbow trout, Oncorhynchus 
mykiss (Walbaum, 1792) and sturgeon, Acipenser naccarii Bonaparte, 1836] we found much lower oxidative levels in the brain lipids of the sturgeon than in the trout (unpublished data). Consequently, we hypothesized that the greater longevity of the sturgeon was possibly related to a better oxidative state of its nervous tissue. Subsequently, Sanz et al. (2013) elucidated the relation between the greater MLSP of different fish species [Squalius pyrenaicus (Günther, 1868), Cyprinus carpio Linnaeus, Carassius auratus Linnaeus, 1758, Luciobarbus sclateri (Günther, 1868) and Oncorhynchus mykiss] and the lower oxidation of the brain. We also found a positive relation between the level of the antioxidant enzymes superoxide dismutase (SOD), the glutathione peroxidase (GPX), the glutathione transferase (GST) and the MLSP in the brain tissue. The importance of the protection of the high lipid content in the nervous tissue in the face of oxidative damage relates to the proper state of functions responsible for life and consequently, for the longevity of a given individual and the MLSP of a given species (Sanz et al., 2013). Moreover, the previous results obtained in different parameters indicative of oxidative status in four insects species in the nymphal stage of the aquatic insect order Plecoptera [Perla marginata (Panzer, 1799), Guadalgenus franzi (Aubert, 1963), Isoperla morenica Tierno de Figueroa \& Luzón-Ortega, 2011 (under the name I. curtata Navás, 1924), and I. grammatica (Poda, 1761)] indicate that all of these species showed an important antioxidant activity and that the differences found among species seemed to be mainly due to the duration of the nymphal developmental period (Sanz et al., 2010).

Despite the different studies that were conducted, some authors still considered the role of oxidative stress as a determinant of the longevity of the organism to be an open question (Buffenstein et al., 2008; Page et al., 2010; Gil del Valle, 2011; Montgomery et al., 2011). A large number of environmental factors can induce oxidative stress in animals, including: oxygen (Hetz and Bradley 2005; Lushachack et al., 2005; Storey and Storey, 2010; Costantini, 2014; Hermes-Lima et al., 2015), temperature (Laurette et al., 2011; Jena et al., 2013) and feeding habits (Barbehenn, 2002, 2003; Kim et al., 2007; Martínez-Álvarez et al., 2005; Sanz et al., 2010) are directly related to ROS production (Ahmad, 1995). Oxidative stress is a strong evolutionary and ecological force (Costantini et al., 2010; Costantini, 2014).

In this work, we studied the oxidative state of nine taxa of aquatic insects to relate their antioxidant capacity and the oxidative damage with the characteristics of their environment, their biology and MLSP. Our main objective was to study aquatic insects under their natural conditions We chose a descriptive and correlational approach rather than a more experimental one (for example, controlling for environmental factors in the laboratory) to obtain more realistic information. The studied taxa from five different
Hexapoda orders are Serratella ignita (Poda, 1761), Ephemera danica Müller, 1764 (Ephemeroptera), Crocothemis erythraea (Brullé, 1832) (Odonata), Dinocras cephalotes (Curtis, 1827), Perla bipunctata Pictet, 1833, I. morenica Tierno de Figueroa \& Luzón-Ortega, 2011 (Plecoptera), Notonecta maculata Fabricius, 1794, Gerris sp. (Hemiptera), and Hydropsyche sp. (Trichoptera), all which are immatures (nymph/larva) and approximately in an intermediate stage of their development, many of them with different MLSPs. For each taxon, we assessed the antioxidant capacity through the determination of the troloxequivalent antioxidant capacity (TEAC), ferric-reducing/ antioxidant power (FRAP) and the activity of the antioxidant enzymes catalase (CAT), DT-diaphorase (DTD), glutathione peroxidase (GPX), glutathione reductase (GR), glutathione transferase (GST), superoxide dismutase (SOD) as well as glucose-6-phosphate dehydrogenase (G6PDH). Furthermore, to determine the oxidative damage, we examined thiobarbituric acid reactive substances (TBARs), free malondialdehyde (FrMDA), protein-bound malondialdehyde (PrMDA), total hydroperoxides (LOOH) and protein hydroperoxides $(\mathrm{PrOOH})$.

\section{METHODS}

\section{Collection, locations and samplings}

Specimens of nine aquatic insect taxa listed above were collected during the spring of 2014 from four different freshwater systems:

- River Despeñaperros (Sierra Morena, Jaén, Spain; $38^{\circ} 22^{\prime} 22.98^{\prime \prime} \mathrm{N}, 3^{\circ} 30^{\prime} 26.25^{\prime \prime} \mathrm{W}, 560 \mathrm{~m}$ asl), a slow-flowing Mediterranean seasonal stream with relatively warm water $\left(9.6-17.9^{\circ} \mathrm{C}\right.$ during the collection period) and a intermediate oxygen level. Collected taxa: S. ignita and I. morenica.

- River Castril (Sierra de Castril, Granada, Spain; $37^{\circ} 52^{\prime} 37.6^{\prime \prime} \mathrm{N}, 2^{\circ} 45^{\prime} 26.1^{\prime \prime} \mathrm{W}, 1040 \mathrm{~m}$ asl), a fast-flowing Mediterranean-type permanent stream with cold (9.3$12^{\circ} \mathrm{C}$ during the collection period) and well-oxygenated water. Collected taxa: D. cephalotes, P. bipunctata and Hydropsyche sp.

- Charca del Cañaveral (Sierra de Huétor, Granada,

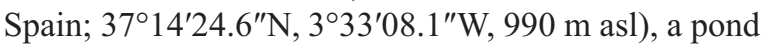
with warm $\left(12.5-14.0^{\circ} \mathrm{C}\right.$ during the collection period) and little oxygenated water. Collected taxa: C. erythraea, N. maculata and Gerris sp.

- River Aguas Blancas (between Sierra Nevada and Sierra

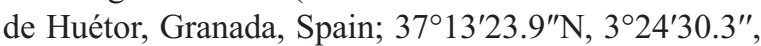
$1140 \mathrm{~m}$ asl), a permanent Mediterranean stream with cold (7.0-13. $0^{\circ} \mathrm{C}$ during the collection period), well-oxygenated water. Collected taxon: E. danica.

All taxa were collected in the nymphal/larval stage of the life cycle and at approximately the same developmental 
stage in order to compare organisms in the same physiological stage. They were sampled using a kick net $(250 \mu \mathrm{m}$ mesh size), immediately placed in liquid nitrogen and stored at $-80^{\circ} \mathrm{C}$ until the laboratory analyses. The studied taxa were selected according to their different habitat preferences and life histories. Data on the biology of these taxa are reported in Tab. 1.

\section{Treatment of samples}

Enzymatic determinations were performed using the whole individuals. Animal samples (approximately eight animals per sample, eight replicates per species) were homogenized in ice-cold distilled water $(1 / 9, \mathrm{w} / \mathrm{v})$ with an electric homogenizer (Heidolph Instruments). The homogenates were centrifuged at $30000 \mathrm{~g}$ for $30 \mathrm{~min}$ at $4^{\circ} \mathrm{C}$ in a model $3 \mathrm{~K} 30$ Sigma centrifuge. After centrifugation, the supernatant was collected and frozen at $-80^{\circ} \mathrm{C}$ until analysis. All enzymatic assays were performed at $25 \pm 0.5$ ${ }^{\circ} \mathrm{C}$. Each sample was tested twice in 96-well microplates (UVStar ${ }^{\circledR}$, Greiner Bio-one, Germany) using a PowerWavex microplate scanning spectrophotometer (Bio-tek Instruments, USA). The enzymatic reactions were started by the addition of the tissue extract, with the exception of the SOD reaction in which xanthine oxidase was used. The specific assay conditions were as follows.

\section{Determination of antioxidant capacity}

To assess the antioxidant capacity, the trolox-equivalent antioxidant capacity (TEAC) (Erel, 2004) and ferricreducing/antioxidant power FRAP (Benzie and Strain, 1996), as well as a set of antioxidant enzymes such as superoxide dismutase (SOD), catalase (CAT), glutathione peroxidase (GPX), glutathione reductase (GR), glu- tathione S-transferase (GST), and DT-diaphorase (DTD), were measured (Sanz et al., 2014).

TEAC was measured according to Erel (2004). ABTS (2,2'-azinobis-3-ethylbenzothiazoline-6-sulphonic acid) in an acidic medium that is oxidized by hydrogen peroxide, turning an emerald-green colour. The reduction of this compound in the presence of antioxidants results in a loss of colour, measured at $595 \mathrm{~nm}$, proportional to the total antioxidant capacity of the extract. Antioxidant activity refers to the equivalent of a water-soluble analogue of vitamin E (Trolox) used as a standard. The results are expressed in terms of $\mu \mathrm{mol}$ of Trolox-equivalent antioxidant capacity per litre of tissue extract $(\mu \mathrm{M})$.

FRAP measures the antioxidant power of a sample according to its ability to reduce the ferric iron $\left(\mathrm{Fe}^{+3}\right)$ that is present in a complex with 2,4,6-tri(2-pyridyl)-s-triazine (TPTZ) to the ferrous form $\left(\mathrm{Fe}^{+2}\right)$. This test was performed in an acetic acid-sodium acetate buffer ( $\mathrm{pH}$ of 3.4) containing TPTZ and $\mathrm{FeCl}_{3}$. After 60 min of reaction, the absorbance was determined at a wavelength of $593 \mathrm{~nm}$. The reference curve was constructed using ascorbic acid as a primary standard. The activities of the samples were expressed as ascorbic acid equivalent antioxidant capacity (AEAC: $\mathrm{mg}$ of ascorbic acid/100 $\mathrm{g}$ of extract).

The SOD (EC 1.15.1.1) activity was measured spectrophotochemically by the ferricytochrome $\mathrm{C}$ method using xanthine/xanthine oxidase as the source of superoxide radicals. The reaction mixture comprised $50 \mathrm{mM}$ potassium phosphate buffer ( $\mathrm{pH}$ of 7.8), $0.1 \mathrm{mM}$ EDTA, $0.1 \mathrm{mM}$ xanthine, $0.013 \mathrm{mM}$ cytochrome $\mathrm{c}$, and $0.024 \mathrm{IU}$ $\mathrm{mL}^{-1}$ xanthine oxidase. One activity unit was defined as the amount of enzyme necessary to bring about a $50 \%$ inhibition of the ferricytochrome $\mathrm{c}$ reduction rate measured at $550 \mathrm{~nm}$ (McCord and Fridovich, 1969).

Tab. 1. Biological and autecological traits of the studied taxa.

\begin{tabular}{|c|c|c|c|}
\hline Taxa & Main food source & Life cycle duration (years) & Habitat \\
\hline \multicolumn{4}{|l|}{ Ephemeroptera } \\
\hline Serratella ignita* & Detritus, diatoms & 1 & Benthos \\
\hline Ephemera danica ${ }^{\circ}$ & Detritus, coarse organic matter & 2 & Benthos (burrower) \\
\hline \multicolumn{4}{|l|}{ Odonata } \\
\hline Crocothemis erythraea & Prey & $<1$ & Benthos \\
\hline \multicolumn{4}{|l|}{ Plecoptera } \\
\hline Dinocras cephalotes $\$$ & Prey & 2 & Benthos \\
\hline Perla bipunctata & Prey & $2-3$ & Benthos \\
\hline Isoperla morenica ${ }^{\$}$ & Detritus, diatoms, prey & 1 & Benthos \\
\hline \multicolumn{4}{|l|}{ Hemiptera } \\
\hline Notonecta maculata** & Prey & $\leq 1$ & Nekton \\
\hline Gerris sp. ${ }^{\circ}$ & Prey & $\leq 1$ & Neuston \\
\hline $\begin{array}{l}\text { Trichoptera } \\
\text { Hydropsyche sp.** }\end{array}$ & Detritus and prey & $\leq 1$ & Benthos \\
\hline
\end{tabular}

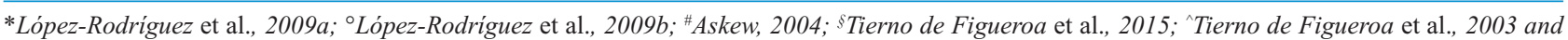
unpublished data; ${ }^{\$}$ López-Rodriguez et al., 2009c; **Tachet et al., 2010; ${ }^{\circ}$ Pfenning and Poethke, 2006. 
The CAT (EC 1.11.1.6) activity was determined spectrophotochemically by measuring the decrease in the $\mathrm{H}_{2} \mathrm{O}_{2}$ concentration at $240 \mathrm{~nm}$ (Aebi, 1984). The reaction mixture contained $50 \mathrm{mM}$ potassium phosphate buffer ( $\mathrm{pH}$ of 7.0) and $10.6 \mathrm{mM} \mathrm{H}_{2} \mathrm{O}_{2}$ (freshly prepared).

The GPX (EC 1.11.1.9) activity was measured following the method of Flohé and Günzler (1984). A freshly prepared glutathione reductase solution $\left(2.4 \mathrm{U} \mathrm{mL}^{-1}\right.$ in $0.1 \mathrm{M}$ potassium phosphate buffer, $\mathrm{pH}$ of 7.0) was added to $50 \mathrm{mM}$ potassium phosphate buffer ( $\mathrm{pH}$ of 7.0), $0.5 \mathrm{mM}$ EDTA, 1 $\mathrm{mM}$ sodium azide, $0.15 \mathrm{mM} \mathrm{NADPH}$, and $0.15 \mathrm{mM}$ cumene hydroperoxide $(\mathrm{CumOOH})$. After the addition of 1 mM GSH (reduced glutathione), the NADPH-consumption rate was monitored spectrophotochemically at $340 \mathrm{~nm}$.

The GR (EC 1.6.4.2) activity was assayed using methods described by Carlberg andMannervik (1975), with some modifications, by measuring the oxidation of $\mathrm{NADPH}$ at $340 \mathrm{~nm}$. The reaction mixture consisted of 0.1 M sodium phosphate buffer ( $\mathrm{pH} 7.5$ ), 1 mM EDTA, 0.63 mM NADPH, and $0.15 \mathrm{mM}$ GSSG.

The GST (EC 2.5.1.18) activity was determined by the method of Habig et al. (1974) adapted to a microplate. The reaction mixture comprised $0.1 \mathrm{M}$ phosphate buffer (pH 6.5), $1.2 \mathrm{mM} \mathrm{GSH}$, and $1.23 \mathrm{mM}$ solution of 1chloro-2,4- dinitrobenzene in ethanol, which was prepared just before the assay. The GST activity was monitored spectrophotochemically at $340 \mathrm{~nm}$ by the formation of glutathione-CDNB-conjugate.

The DTD (EC 1.6.99.2) activity was measured according to Sturve et al. (2005). The reaction mixture contained

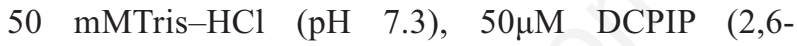
dichlorophenol indophenol) and $0.5 \mathrm{~m}$ MNADH. The control reaction contained distilled water instead of the sample extract. The DTD activity is defined as the difference between the sample and the control in the DCPIP reduction reaction.

Except for SOD (the arbitrary units of which have been mentioned above), for every other enzymatic activity, one unit of activity is defined as the amount of enzyme required to transform $1 \mu \mathrm{mol}$ of substrate/min under the aforementioned assay conditions (Sanz et al., 2010). To estimate the enzyme-specific activity, the soluble protein of the extracts was determined by a bicinchoninic acid protein assay reagent (Thermo Scientific, Pierce Biotechnology, Rockford, IL, USA) using bovine serum albumin as the standard.

For G6PDH (EC 1.1.1.49) the change in the absorbance of NADPH at $340 \mathrm{~nm}$ was monitored to determine the enzymatic activity (millimolar extinction coefficient, 6.22). The reaction mixture contained $50 \mathrm{mM}$ imidazole- $\mathrm{HCl}$ buffer ( $\mathrm{pH}$ of 7.4), $5 \mathrm{mM} \mathrm{MgCl} 2,2 \mathrm{mM}$ NADP, and $1 \mathrm{mM}$ glucose-6-phosphate (Morales et al., 1990). The enzyme activities are reported in milliunits (nmol of substrate transformed per minute) per mg of protein.

\section{Determination of oxidative damage}

To quantify the oxidative damage, the following lipid and protein peroxidation biomarkers were evaluated: free malondialdehyde (FrMDA), protein-bound malondialdehyde (PrMDA), lipid hydroperoxides ( $\mathrm{LOOH}$ ), protein hydroperoxides (PrOOH) (Grintzalis et al., 2013), and thiobarbituric acid-reactive substances (TBARs) (Buege and Aust, 1978). The reason we measure TBARs as a measurement of oxidative damage in a whole sample, together with FrMDA, PrMDA, LOOH and PrOOH measurements, is to determine the degree of oxidation in the three main fractions, i.e., aqueous, lipid and protein. Higher levels of oxidation in the aqueous fraction could be related with higher and more advanced oxidation of molecules, assuming that free MDA is the oxidized molecule in organisms. The sum of FrMDA, PrMDA, LOOH and PrOOH quantifies the total oxidative damage (TOD) and could be used as a tool for comparison of global oxidative damage.

At the first step, each sample was divided into two homogenates of $0.5 \mathrm{~mL}$, which were mixed with $1 \mathrm{~mL}$ of chlorophorm:methanol (2:1) followed by vigorous vortexing (Nahita $\odot$ vortex); then, $150 \mu \mathrm{l}$ of $100 \%$ TCA (trichloroacetic acid) was added to the resulting mixture and briefly vortexed. After 20 min of incubation in an icewater bath, the samples were centrifuged at $20000 \mathrm{~g}$ for 10 $\mathrm{min}$. As a result of this process, three layers were formed: an upper aqueous layer, an intermediate protein disk, and a bottom chloroform layer. The aqueous layers of the two replicates of every sample were combined and stored at $20^{\circ} \mathrm{C}$ to use later for the FrMDA determination. The combination of the two chloroform layers was concentrated by a continuous flow of nitrogen and stored at $-20^{\circ} \mathrm{C}$ for the $\mathrm{LOOH}$ assay. One of the resulting disks of protein was solubilized in $1500 \mu \mathrm{L} \mathrm{NaOH} 0.1 \mathrm{mM}$ and incubated at $60^{\circ} \mathrm{C}$ for $30 \mathrm{~min}$ to hydrolyse PrMDA from the protein-MDA complex. This was immediately cooled in an ice-water bath and centrifuged at $20000 \mathrm{~g}$ for $5 \mathrm{~min}$; simultaneously, the supernatant was collected, stored at $-20^{\circ} \mathrm{C}$ and then used for PrMDA measurement. The other resulting disk of protein was solubilised in $1800 \mu \mathrm{L} 0.1 \mathrm{M} \mathrm{NaOH}$ and neutralized with $200 \mu \mathrm{L} 1 \mathrm{M} \mathrm{HCl}$, stored directly at $-20^{\circ} \mathrm{C}$, and afterwards used for $\mathrm{PrOOH}$ measurement.

The same procedure was followed for both the $\mathrm{LOOH}$ and $\mathrm{PrOOH}$ determination. Firstly, the lipid pellet was dissolved in $2000 \mu \mathrm{L}$ of absolute methanol for the $\mathrm{LOOH}$ assay. For both, the sample was incubated for $30 \mathrm{~min}$ with or without the presence of $\mathrm{Fe}^{+2}$. The final concentrations of reagents for the $+\mathrm{Fe}$ sample were $92.5 \%$ methanol, $100 \mu \mathrm{M}$ xylenol orange, $12.5 \mathrm{mM} \mathrm{H}_{2} \mathrm{SO}_{4}$, and $200 \mu \mathrm{M} \mathrm{Fe}{ }^{2+}$, whereas the final concentrations of reagents for the $-\mathrm{Fe}$ sample were $92.5 \%$ methanol, $100 \mu \mathrm{M}$ XO, and $12.7 \mathrm{mM}$ $\mathrm{H}_{2} \mathrm{SO}_{4}$. The absorbance was measured at $560 \mathrm{~nm}$, and the net absorbance difference was calculated as (Sample $+\mathrm{Fe})$ - (Blank reagent $+\mathrm{Fe})$, from which the absorbance differ- 
ence (Sample-Fe) - (Blank reagent-Fe) was subtracted. For $\mathrm{LOOH}$, the net absorbance was converted to $\mathrm{CumOOH}$ concentration equivalents using a standard curve $(0-20 \mu \mathrm{M})$ or converted to $\mathrm{H}_{2} \mathrm{O}_{2}$ concentration equivalents using a standard curve $(0-40 \mu \mathrm{M})$ for PrOOH. The results were expressed as $\mu \mathrm{mol}$ equivalents $\mathrm{CumOOH} / \mathrm{mg}$ protein of the original homogenate ( $\mathrm{LOOH}$ ) or $\mu \mathrm{mol} \mathrm{H}_{2} \mathrm{O}_{2} / \mathrm{mg}$ protein equivalents of the $\mathrm{PrOOH}$ fraction $(\mathrm{PrOOH})$.

For both PrMDA and FrMDA, the same procedure was followed. The samples were incubated with a final reagent concentration of $7 \%$ TCA, $0.21 \%$ TBA (thiobarbituric acid), and $1 \mathrm{mM} \mathrm{BHA} \mathrm{(butylhydroxyanisole)} \mathrm{for}$ the sample reaction or 7\% TCA and $1 \mathrm{mM} \mathrm{BHA}$ for the sample blank for $20 \mathrm{~min}$ at $100^{\circ} \mathrm{C}$. Then, the samples were cooled in an ice-water bath and centrifuged at $10000 \mathrm{~g}$ for $3 \mathrm{~min}$. The absorbance of the supernatant was measured at $535 \mathrm{~nm}$. The net absorbance (sample reaction - sample blank) was converted to MDA (malondialdehyde) concentrations from the corresponding standard curve, prepared in $0.1 \mathrm{M} \mathrm{NaOH}$ solution (0-15 $\mu \mathrm{M}$ MDA) for PrMDA determination or prepared in an extraction solution (100 mM phosphate buffer, $0.5 \mathrm{mM}$ BHA, 33\% methanol, $13.3 \%$ TCA) $(0-40 \mu \mathrm{M})$ for the FrMDA assay. The results are expressed as $\mu \mathrm{mol} \mathrm{MDA} / \mathrm{mg}$ protein of the PrMDA fraction (PrMDA) or $\mu \mathrm{mol} \mathrm{MDA} / \mathrm{mg}$ protein of the original homogenate (FrMDA).

For all biochemical variables, two measurements were taken from each aliquot, and the average was used in the statistical analyses. All biochemical reagents, including substrates, coenzymes, and purified enzymes, were obtained from Roche (Mannheim, Germany), Sigma Chemical Co. (St. Louis, MO, USA) or Merck (Darmstadt, Germany). The lipid and protein peroxidation products in the samples, FrMDA and PrMDA, are expressed as $\mu \mathrm{mol}$ MDA, $\mathrm{LOOH}$ are expressed as $\mu \mathrm{mol} \mathrm{CumOOH}$ equivalents and $\mathrm{PrOOH}$, are expressed as $\mu \mathrm{mol} \mathrm{H}_{2} \mathrm{O}_{2}$ equivalents. The values are expressed as per mg protein as determined using the BCA method. Furthermore, another index of oxidative damage widely used was measured in the same samples: the lipid-peroxidation levels were determined based on the malondialdehyde levels (MDA) generated as a product of lipid peroxide degradation. In the presence of thiobarbituric acid, MDA reacts to produce a coloured thiobarbituric acid-reacting substance (TBAR) that was measured at $535 \mathrm{~nm}$ and was expressed as nmol MDA per $g$ tissue.

All biochemicals, including the substrates, the coenzymes, and the purified enzymes, were obtained from Roche or Sigma Chemical Co. All other chemicals were obtained from Merck and were of reagent grade. The plasma glucose, total lipid, triglyceride, and cholesterol levels were assayed using standard colorimetric tests (Labkit 30232, 30345, 30360, 30180, CHEMELEX S.A., Barcelona, Spain).

\section{Statistical analyses}

The results are expressed as the means \pm SEM. The data were statistically analysed by a one-way analysis of variance (ANOVA, SPSS version 19.0 for Windows) to assess the significance of the differences between taxa. When these differences were significant $(\mathrm{P}<0.05)$, the taxa were compared using a Duncan's multiple range test (Duncan, 1955). Pearson's correlations were generated to examine the relationships among all of the variables.

Parametric tests were used because the data followed a normal distribution (Kolmogorov-Smirnov with $\mathrm{P}>0.05$ ) and had homocedasticity (Levene test with $\mathrm{p}>\mathrm{P} .05$ ).

\section{RESULTS}

The soluble protein content in the body tissues was significantly lower in I. morenica and E. danica. In contrast, a higher lipid content was found in I. morenica (Tab. 2).

\section{Antioxidant capacity}

The highest values of trolox-equivalent antioxidant capacity (TEAC) were found in I. morenica, P. bipunctata and C. erythraea (Tab. 3), and the lowest values are found in Hydropsyche sp., Gerris sp. and E. danica.

Regarding FRAP (Tab. 3), the highest values were present in S. ignita and C. erythraea, and the lowest were present in Gerris sp., D. cephalotes, P. bipunctata and E. danica. The highest levels for each enzyme (Tab. 3) were recorded as follows: N. maculata, Gerris sp. and E. danica for SOD; I. morenica for CAT; S. ignita for GR; $D$. cephalotes, P. bipunctata and I. morenica for GPX; P. bipunctata, I. morenica, N. maculata, Gerris sp. and $C$. erythraea for GST; I. morenica for DTD, and Gerris sp. for G6PDH.

On the other hand, the lowest levels of each enzyme

Tab. 2. Protein and lipid-soluble content in the studied taxa of aquatic insects.

\begin{tabular}{lcc} 
& Lipids $(\mathrm{g} / \mathrm{mL})$ & Proteins $(\mathrm{mg} / \mathrm{mL})$ \\
Serratella ignita & $0.097^{\mathrm{cd}} \pm 0.002$ & $4.689^{\mathrm{b}} \pm 0.073$ \\
\hline Ephemera danica & $0.078^{\mathrm{a}} \pm 0.001$ & $3.186^{\mathrm{a}} \pm 0.257$ \\
\hline Crocothemis erythraea & $0.079^{\mathrm{a}} \pm 0.002$ & $4.260^{\mathrm{ab}} \pm 0.643$ \\
\hline Dinocras cephalotes & $0.082^{\mathrm{ab}} \pm 0.000$ & $5.961^{\mathrm{c}} \pm 0.180$ \\
\hline Perla bipunctata & $0.094^{\mathrm{bcd}} \pm 0.005$ & $6.006^{\mathrm{c}} \pm 0.496$ \\
\hline Isoperla morenica & $0.102^{\mathrm{d}} \pm 0.007$ & $3.089^{\mathrm{a}} \pm 0.072$ \\
\hline Notonecta maculata & $0.090^{\mathrm{abc}} \pm 0.001$ & $5.872^{\mathrm{c}} \pm 0.611$ \\
\hline Gerris sp. & $0.086^{\mathrm{abc}} \pm 0.005$ & $6.038^{\mathrm{c}} \pm 0.345$ \\
\hline Hydropsyche sp. & $0.086^{\mathrm{abc}} \pm 0.001$ & $5.006^{\mathrm{bc}} \pm 0.427$ \\
\hline
\end{tabular}

Values are mean $\pm \operatorname{SEM}(N=8)$. Superscripts letters indicate significant differences among different species $(P<0.05)$. 
were found in the following: S. ignita for SOD; S. ignita, N. maculata and C. erythraea for CAT; P. bipunctata, Gerris sp., E. danica and C. erythraea for GR; Hydropsyche sp., S. ignita and E. danica for GPX; D. cephalotes, S. ignita, E. danica and Hydropsyche sp. for GST; S. ignita, Gerris sp., E. danica and C. erythraea for DTD; and C. erythraea, I. morenica and E. danica for G6PDH.

\section{Oxidative damage}

The highest values of TBARs were present in S. ignita and $E$. danica, while the lowest values were recorded in D. cephalotes (Tab. 4).

For PrMDA, the highest values were found in $I$. morenica, S. ignita and C. erythraea; however, in D. cephalotes and E. danica, PrMDA was not detected. The highest values of $\mathrm{PrOOH}$ were detected in S. ignita and E. danica, whereas in D. cephalotes and P. bipunctata, PrOOH was not detected. The highest value of FrMDA was present in S. ignita, and the lowest FrMDA values were found in D. cephalotes, P. bipunctata and Hydrospyche sp. The highest value of $\mathrm{LOOH}$ was found in $H y$ dropsyche sp., and the lowest was found in N. maculata.

A strong positive correlation was found between TBARs and FrMDA (Pearson $\mathrm{r}=0.815 ; \mathrm{P}<0.0001$ ) and between TBARs and PrOOH $(r=0.801 ; \mathrm{P}<0.0001)$. Significant correlations were also found between FrMDA and PrMDA ( $r=0.740 ; \mathrm{P}<0.0001)$, FrMDA and $\mathrm{PrOOH}$ $(r=0.931 ; \mathrm{P}<0.0001)$, and PrMDA and $\mathrm{PrOOH}(\mathrm{r}=0.826$; $\mathrm{P}<0.0001)$.

\section{DISCUSSION}

\section{Antioxidant capacity}

To accurately test the antioxidant state of the nine insect species, we used three separate techniques (TEAC, FRAP and antioxidant enzymes). We found a correspondence among the values obtained in TEAC and FRAP for the studied species. Moreover, the FRAP values were higher than the TEAC values for each species, except $S$. ignita, N. maculata and Hydropsyche sp. Although both techniques determined substances with antioxidant power, the determination of TEAC assumes the assessment of $53.0 \%$-SH groups of proteins, $33.1 \%$ uric acid, $4.7 \%$ vitamin $\mathrm{C}, 2.4 \%$ bilirubin, $1.7 \%$ vitamin $\mathrm{E}$ and $5.2 \%$ others (glutathione, etc.) (Erel, 2004). However, FRAP assesses the capacity of a given substance to reduce ferric iron, and is also considered a measure of the total antioxidant power. It treats reducers and antioxidants equally; however, not all reducers that transform ferrous iron to ferric iron are antioxidants, and some antioxidants cannot produce that reaction, as is the case of glutathione, which can be determined by means of TEAC (Prior and Cao, 1999). Nevertheless, both techniques (TEAC and FRAP) can be

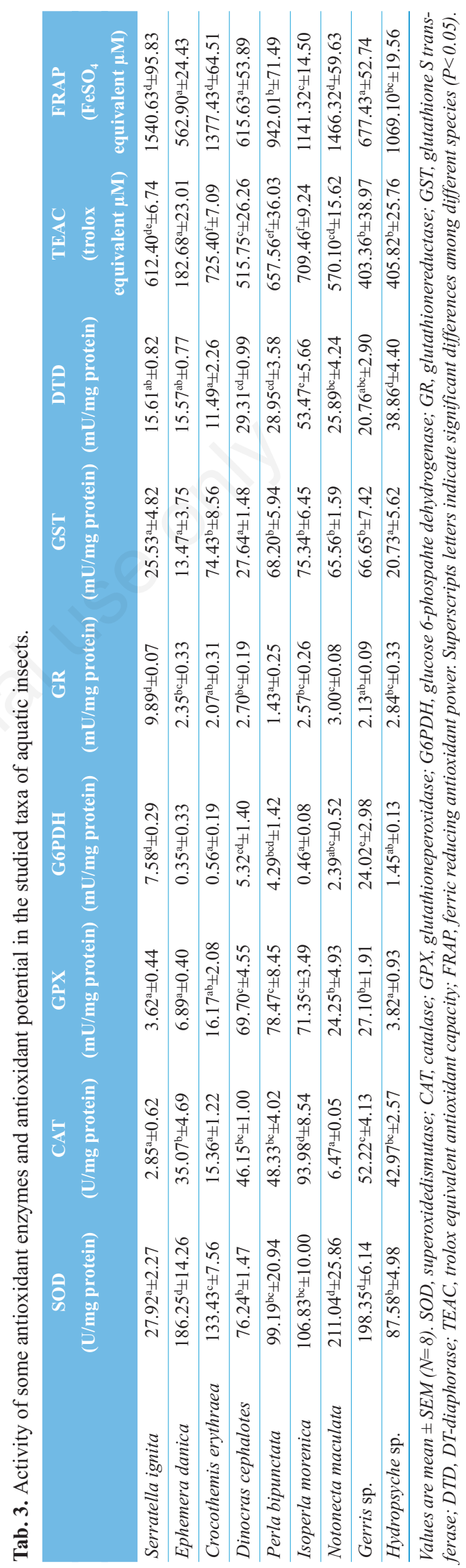


considered as indicative of some form of antioxidant capacity of the tissue from which they are determined. In fact, we find that the species S. ignita, I. morenica, C. erythraea and N. maculata are notable for a higher antioxidant power as indicated by both techniques (Fig. 1), and
Gerris sp. and E. danica had the lowest capacity. If the sum of the antioxidant enzymes are considered together with the antioxidant capacity determined by TEAC and FRAP (TAC, Fig. 1), the same results were obtained. Specimens of S. ignita, I. morenica, C. erythraea and

Tab. 4. Values of different parameters of oxidative damage in the studied taxa of aquatic insects.

\begin{tabular}{|c|c|c|c|c|c|}
\hline & $\begin{array}{c}\text { LOOH } \\
\text { ( } \mu \text { moleqCumO } \\
\text { OH/mg lipid) }\end{array}$ & $\begin{array}{c}\text { FrMDA } \\
\text { ( } \mu \text { molMDA/ } \\
\text { mg lipid })\end{array}$ & $\begin{array}{c}\text { PrMDA } \\
(\text { molMDA/ } \\
\text { mg protein) }\end{array}$ & $\begin{array}{c}\mathrm{PrOOH} \\
\left(\mu \mathrm{mol} \text { eqH } \mathrm{H}_{2} \mathrm{O}_{2} /\right. \\
\text { mg protein) }\end{array}$ & $\begin{array}{c}\text { TBARs } \\
\text { (umolMDA/ } \\
\mathrm{g} \text { tissue) }\end{array}$ \\
\hline Serratella ignita & $0.048^{\mathrm{bc}} \pm 0.001$ & $0.159^{\mathrm{d}} \pm 0.000$ & $16.45^{\mathrm{c}} \pm 0.9$ & $10.20^{\mathrm{d}} \pm 0.7$ & $40.85^{\mathrm{e}} \pm 3.11$ \\
\hline Ephemera danica & $0.048^{\mathrm{bc}} \pm 0.002$ & $0.070^{c} \pm 0.003$ & $5.24^{\mathrm{a}} \pm 0.00$ & $6.66^{\mathrm{c}} \pm 0.54$ & $32.51^{\mathrm{d}} \pm 2.27$ \\
\hline Crocothemis erythraea & $0.045^{\text {bc }} \pm 0.003$ & $0.078^{\mathrm{c}} \pm 0.003$ & $7.09^{b} \pm 0.63$ & $3.17^{b} \pm 0.21$ & $17.12^{\mathrm{b}} \pm 0.61$ \\
\hline Dinocras cephalotes & $0.095^{\mathrm{d}} \pm 0.004$ & $0.035^{\mathrm{a}} \pm 0.004$ & $3.44^{\mathrm{a}} \pm 0.21$ & n.d. & $11.08^{\mathrm{a}} \pm 1.01$ \\
\hline Perla bipunctata & $0.059^{\mathrm{c}} \pm 0.008$ & $0.031^{\mathrm{a}} \pm 0.004$ & $4.17^{\mathrm{a}} \pm 0.20$ & n.d. & $21.61^{\mathrm{bc}} \pm 1.00$ \\
\hline Isoperla morenica & $0.036^{\mathrm{b}} \pm 0.005$ & $0.077^{\mathrm{c}} \pm 0.003$ & $16.98^{\mathrm{c}} \pm 1.2$ & $5.58^{\mathrm{c}} \pm 0.32$ & $16.61^{\mathrm{b}} \pm 1.71$ \\
\hline Notonecta maculata & $0.017^{\mathrm{a}} \pm 0.000$ & $0.054^{\mathrm{b}} \pm 0.005$ & $3.36^{\mathrm{a}} \pm 0.09$ & $2.12^{\mathrm{a}} \pm 0.20$ & $20.25^{\mathrm{bc}} \pm 1.02$ \\
\hline Gerris sp. & $0.043^{b} \pm 0.008$ & $0.055^{b} \pm 0.005$ & $3.56^{\mathrm{a}} \pm 0.37$ & $3.06^{\mathrm{b}} \pm 0.10$ & $17.83^{\mathrm{b}} \pm 1.73$ \\
\hline Hydropsyche sp. & $0.157^{\mathrm{e}} \pm 0.004$ & $0.041^{\mathrm{a}} \pm 0.001$ & $4.20^{\mathrm{a}} \pm 0.22$ & $1.30^{\mathrm{a}} \pm 0.13$ & $23.74^{\mathrm{c}} \pm 1.76$ \\
\hline
\end{tabular}

Values are mean \pm SEM (N=8). LOOH, lipid hydroperoxides; FrMDA, free malondialdehyde; PrMDA, malondialdehyde associated to protein; PrOOH, protein hydroperoxides; TBARs, thiobarbituric acid reactive substances; $n$.d., non detectable. Superscripts letters indicate significant differences among different species $(P<0.05)$.

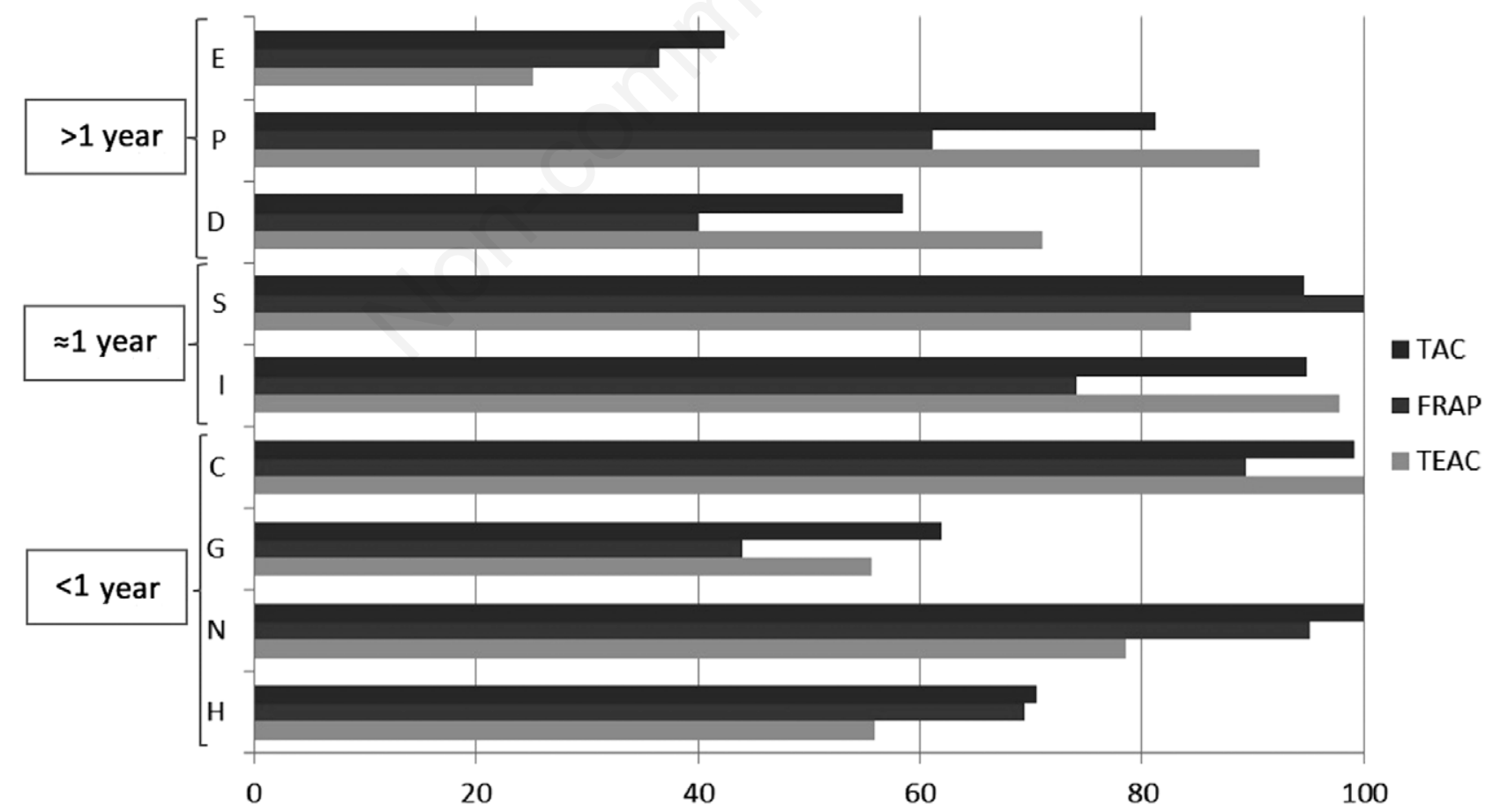

Fig. 1. Trolox-equivalent antioxidant capacity (TEAC), ferric-reducing/antioxidant power (FRAP) and total antioxidant capacity (TAC) for the studied taxa. The parameters are represented as the percentage in relation to the maximum value (100\%) found in a taxon. E, Ephemera danica; P, Perla bipunctata; D, Dinocras cephalotes; S, Serratella ignita; I, Isoperla morenica; C, Crocothemis erythraea; G, Gerris sp.; N, Notonecta maculata; H, Hydropsyche sp. 
N. maculata were collected from warm or relatively warmwaters habitats. It is known that temperature increases metabolic processes, as well requiring higher antioxidant protection due to increase in metabolism (Ahmad and Pardini, 1990). In contrast, Gerris sp. and E. danica had the lowest values of antioxidant capacity as previously mentioned, and both species occur neither in the water column nor on the riverbed (Gerris sp. lives on the surface of the water, and E. danica, a burrowing mayfly nymph, lives primarily in U-shaped tubes excavated in the riverbed, Tab. 1). It is possible that Gerris sp. has a lower energetic cost for locomotion than the other species, resulting in a slower metabolism. However, the oxygen content in the environment that $E$. danica usually inhabits is low (in comparison with other habitats in the same stream); consequently, this species should have a lower formation of free radicals. However, E. danica, unlike Gerris sp., also experiences important oxidative damage (Tab. 4). This and other currently unknown factors associated to its biology may cause this stress, such as the fact that Gerris sp. lives on the water surface where the oxygen level is permanently high if compared with aquatic environments. Moreover, it lives in a environment with rapid temperature changes. Thus, it is necessary to have a better antioxidant protection.

The remaining species (Hydropsyche sp., P. bipunctata and $D$. cephalotes) had a total antioxidant capacity half that of the previously mentioned species (Fig. 1). The occurrence of these three taxa in cold-water streams may explain the lower antioxidant capacity (Tab. 1). The antioxidant potential may be directly related with habitat temperature and with ecological characteristics (benthic, neustonic, etc.) of the habitat of each taxon measured.

The values obtained for TEAC and FRAP were comparable with those of TAEA (the sum of the enzymatic activities of SOD, CAT, GR, GPX, GST and DTD, Fig. 2), except for $S$. ignita in which the TEAC/TAEA and FRAP/TAEA relations are approximately four times higher than in the remaining species. This would indicate a higher proportion of metabolites with antioxidant power relative to the activity of the antioxidant enzymes in S. ignita. Although this species has a very low level of antioxidant enzymes, its GR activity is higher than for the other species (Tab. 3). This indicates that glutathione is important among the antioxidant metabolites due to the important role of GR in its regeneration. The activity of the G6PDH enzyme in this species is exceptional. This enzyme is associated with NADPH production and with the maintenance of GR activity. This higher proportion of antioxidant metabolites may be related to the diet of the nymphs, which feed on diatoms to a large extent (almost one third of their diet), together with detritus in the studied population (López-Rodríguez et al., 2009a). Their great availability in the sampled stream and the characteristics of these trophic resources relative to their antioxidant properties (Bertrand, 2010; Palatal et al., 2016) could promote a higher proportion of antioxidant metabolites relative to the antioxidant enzymatic potential with respect to the remaining species (Fig. 3).

The first studies conducted with insects reported that some antioxidant enzymes were absent in the organisms (Mathews et al., 1997). However, we found all the fundamental antioxidant enzymes are active in our studied aquatic insect species and that there are significant differences among these taxa. This fact has been previously noted also by Berra et al. (2004). In particular, the GPX activity in insects was reported for nymphs of different species of Plecoptera (Sanz et al., 2010, 2014). In these studies, the total GPX activity was assayed, including selenium-dependent and selenium-independent isoforms using a organic peroxide (cumene hydroperoxide) as the substrate. The same protocol was followed in the present study, which could explain the GPX activity that was manifested. In fact, the control reaction without the tissue extract confirmed a GPX activity proportional to the extract concentration. A recent study (Dias et al., 2016) on the GPX activity and the gene encoding the selenium-dependent isoform in the kissing bug, Rhodnius prolixus Stål, 1859, supports our results.

In our study, N. maculata, Gerris sp. and E. danica

TEAC/TAEA
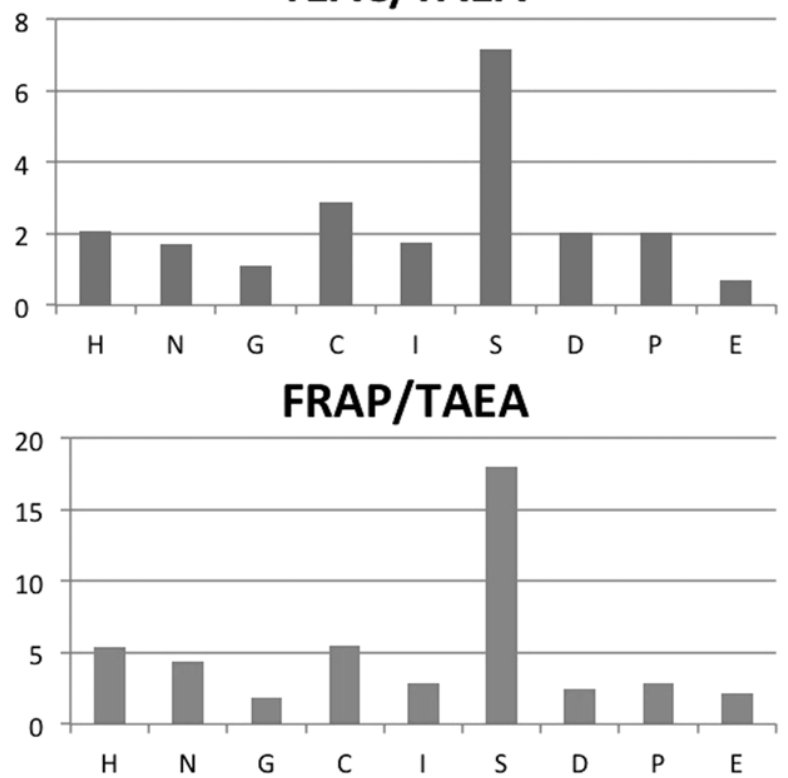

Fig. 2. Relation between TEAC (trolox-equivalent antioxidant capacity, upper graph) and FRAP (ferric-reducing/antioxidant power, down graph) with TAEA, total antioxidant enzyme activity. E, Ephemera danica; P, Perla bipunctata; D, Dinocras cephalotes; S, Serratella ignita; I, Isoperla morenica; C, Crocothemis erythraea; G, Gerris sp.; N, Notonecta maculata; H, Hydropsyche sp. 
were notable for a SOD activity higher than that of the other studied species and I. morenica had high CAT, GPX, GST and DTD activity. All the other studied species have similar values for GST activity, with $S$. ignita, $D$. cephalotes, Hydropsyche sp. and E. danica had the lowest values. The species $I$. morenica, P. bipunctata and $D$. cephalotes had high GPX activity, and they are species with the intermediate or great lipid content. It is known that the GPX plays a protective role for lipids against oxidation (Brigelius-Flohé, 1999). Serratella ignita has high GR activity as mentioned before, and Gerris sp. is notable for its high G6PDH activity, an enzyme in the pentose phosphate pathway with a high reduction power responsible for several functions in the animal organism. Berra et al. (2004) noted that G6PDH activity is very low or undetectable in most taxa, including Plecoptera. In our work, the lowest values corresponded to I. morenica, C. erythraea and Hydropsyche sp., species belonging to three taxonomic groups, Plecoptera, Odonata and Trichoptera, respectively. Our study suggests that the differences in antioxidant enzymes found among distant related taxa are not associated with autecological traits.

\section{Oxidative damage}
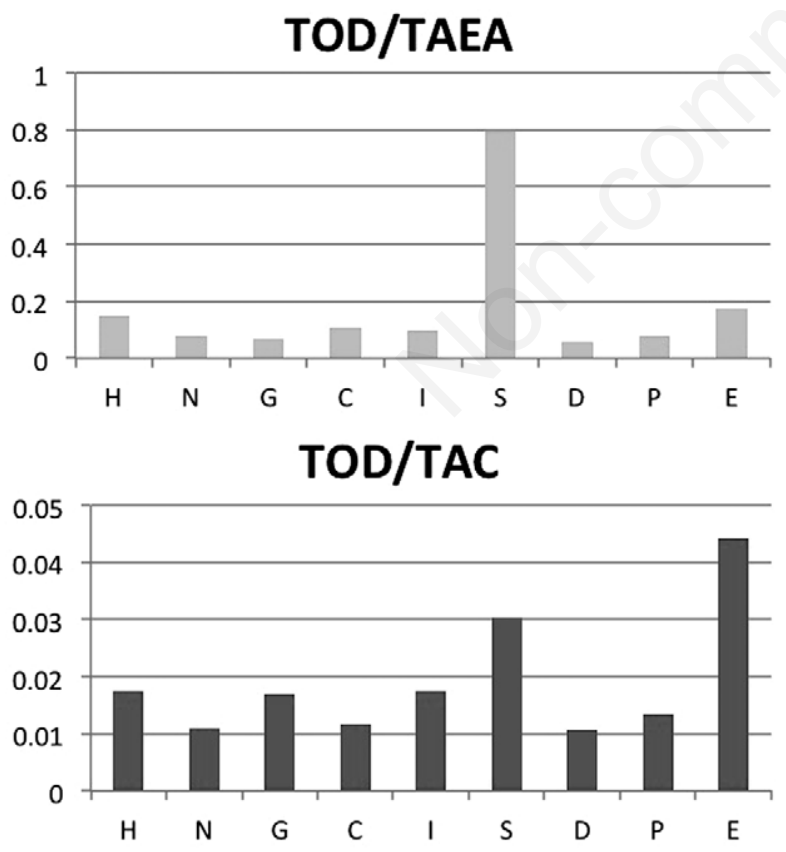

Fig. 3. Relation between TOD, total oxidative damage, with TAEA (total antioxidant enzyme activity, upper graph) and with TAC (total antioxidant activity, down graph). E, Ephemera danica; P, Perla bipunctata; D, Dinocras cephalotes; S, Serratella ignita; I, Isoperla morenica; C, Crocothemis erythraea; G, Gerris sp.; N, Notonecta maculata; $\mathrm{H}$, Hydropsyche sp.
To quantify the oxidative damage, we evaluated lipid and protein peroxidation biomarkers: free malondialdehyde (FrMDA), protein-bound malondialdehyde (PrMDA), total hydroperoxides $(\mathrm{LOOH})$, and protein hydroperoxides (PrOOH) and TBARs (Tab. 4). We found a strong positive correlation between TBARs and FrMDA and between TBARs and PrOOH. There were also correlations between FrMDA and PrMDA, FrMDA and PrOOH, and PrMDA and $\mathrm{PrOOH}$. This indicates that, except for $\mathrm{LOOH}$, the remaining determinations used to indicate oxidative damage have values correlated among them. This allows accuracy in detecting actual oxidative damage.

Fig. 4 presents the sum of all the parameters of oxidative damage (TOD). The species $S$. ignita had the greatest oxidative damage, followed by $E$. danica and I. morenica. The lowest was found in D. cephalotes, followed by $P$. bipunctata. Serratella ignita and I. morenica exhibited a short, univoltine, life cycle (Tab. 1), and both were collected in the same stream with relatively well-oxygenated, warm water, and a temporal regime, i.e., a stream with a flow period of several months and a drought period during summer. They are also the species with the highest lipid content. In contrast, D. cephalotes and P. bipunctata are two long lived Plecoptera predator species (Tab. 1) that were collected from a well-oxygenated fast-flowing cold stream with a permanent hydrological regime. Both of these species have a intermediate body lipid content. Although these two species differ slightly in their oxidative state due to a possible mechanism of coexistence in the same habitat (Sanz et al., 2014), they are notable for their lower oxidative damage compared with the other studied species.

The accumulation of oxidative damage with ageing

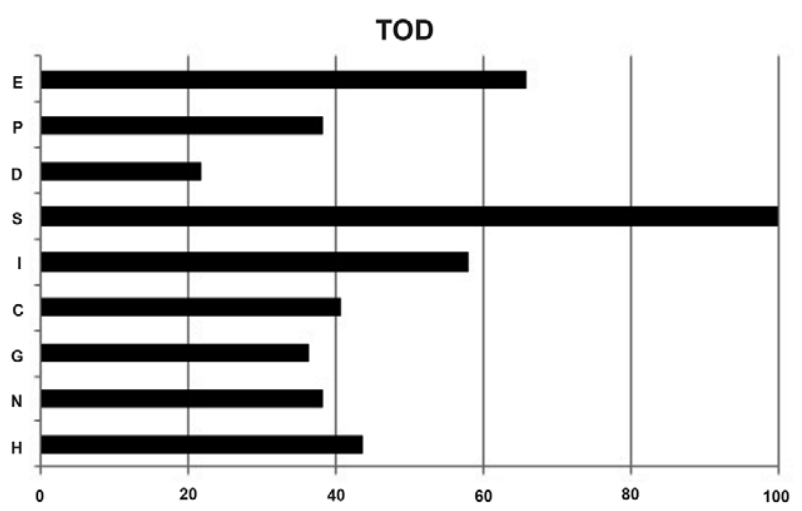

Fig. 4. Total oxidative damage (TOD) for the studied taxa. For each measurement, the species that shows the maximum level is represented as $100 \%$, and the other species reflect the percentage value with respect to this maximum. E, Ephemera danica; P, Perla bipunctata; D, Dinocras cephalotes; S, Serratella ignita; I, Isoperla morenica; C, Crocothemis erythraea; G, Gerris sp.; N, Notonecta maculata; $\mathrm{H}$, Hydropsyche sp. 
has been mentioned by Farooqui and Farooqui (2012) and noted in previous works with fish and other organisms (Sanz et al., 2013). This could partially explain the maximum values of oxidative damage recorded in S. ignita and I. morenica, short-lived species with detritivorous and non-exclusively predator feeding habits, and the minimum values of $D$. cephalotes and $P$. bipunctata, longlived, mainly predator species, as found in this study. The antioxidant machinery (enzymatic and non-enzymatic) in organisms keeps the oxidative species concentration in equilibrium. However, when antioxidant machinery cannot regulate the concentration of pro-oxidant substances, oxidative-stress levels rise (Halliwell and Gutteridge, 1995; Sies, 1997; Halliwell, 2007).

The results obtained in this study could indicate an influence of the life cycle duration, the environment where species live and the taxonomic group to which the species belong (and even of the feeding habits) on the oxidative state of each studied species. Thus, we could differentiate the following three groups:

1) Predator species with a long-life cycle that inhabit permanent streams with well-oxygenated, cold waters $(D$. cephalotes and $P$. bipunctata) have a relatively better oxidative state. Both species belong to the insect order Plecoptera. Isoperla morenica also belongs to the same order and has a high antioxidant potential; however, it also has high oxidative damage. Contrary to $D$. cephalotes and P. bipunctata, this species may act as an omnivore, have a shorter life cycle, and inhabit relatively warmer waters in a temporary stream (Tab. 1).

2) Species with non-exclusively predator feeding habits, from warm, temporal waters and with a short life cycle are those that have the greatest oxidative damage $(S$. ignita and I. morenica; Tab. 1). Isoperla morenica also has a high antioxidant power; thus, the balance between the total antioxidant capacity and the oxidative damage is similar to the other species, contrary to $S$. ignita, which is notable as the species with the poorest oxidative balance. Ephemera danica is a member of the first group based on its life cycle and the temperature of the habitat where it exists (Tab. 1), but the oxidative state of this species is similar to that of $S$. ignita. Although the oxidative damage of E. danica is lower than the one presented by S. ignita, its lower antioxidant capacity generates a high oxidative imbalance. Both species belong to the Ephemeroptera and are detritivorous.

3) The remaining species have an intermediate oxidative state between that of the previous groups. Notonecta maculata, Gerris sp. and C. erythraea were collected in a poorly oxygenated, warm-water pond and have a short life cycle (Tab. 1), although Gerris sp. inhabits on the water surface and is exposed to the oxygen concentration in the atmosphere. Notonecta maculata and
Gerris sp. are Hemiptera. Hydropsyche sp. is a caddisfly (Trichoptera) with an intermediate oxidative state, and it is a species that mixes the biotic and abiotic characteristics of groups 1 and 2 (omnivorous, with a short life cycle and from the cold, well-oxygenated waters of a permanent stream).

\section{CONCLUSIONS}

In summary, predators with a long-life cycle and occurring in permanent streams with cold waters seem to have a proper oxidative state within the insects studied. In contrast, non-exclusively predator species living in temporary streams with warm and poorly oxygenated waters that have a short life cycle have a poorest oxidative state. Therefore, the oxidative state of each species would be defined by an interaction of biological and autecological factors. Future researches are needed to evaluate the relative importance of these factors.

\section{ACKNOWLEDGEMENTS}

Authors are very grateful for the suggestions of two anonymous referees who greatly improved the original version of the manuscript.

\section{REFERENCES}

Aebi H, 1984. Catalase in vitro. Method. Enzymol. 105:121-126. Ahmad S, 1995. Oxidative Stress and Antioxidant Defenses in Biology. Chapman \& Hall, New York:457 pp.

Ahmad S, Pardini RS, 1990. Antioxidant defense of the cabbage looper, Trichoplusia ni: Enzymatic responses to the superoxide-generating flavonoid, quercetin, and photodynamic furanocoumarin, xanthotoxin. Photochem. Photobiol. 51:305-311.

Askew RR, 2004. The dragonflies of Europe. Revised edition. Harley Books, Colchester:308 pp.

Barbehenn RV, 2002. Gut-based antioxidant enzymes in a polyphagous and a graminivorous grasshopper. J. Chem. Ecol. 28:1329-1347.

Barbehenn RV, 2003. Antioxidants in grasshoppers: higher levels defend the midgut tissues of a polyphagous species than a graminivorous species. J. Chem. Ecol. 29:683-702.

Barja G, 2000. The flux of free radical attack through mitochondrial DNA is related to aging rate. Aging-Clin. Exp. Res. 12:342-355.

Barja G, 2004. Aging in vertebrates and the effect of caloric restriction: a mitochondrial free radical production-DNA damage mechanism? Biol. Rev. 79:235.251.

Barja G, Herrero A, 2000. Oxidative damage to mitochondrial DNA is inversely related to maximum life span in the heart and brain of mammals. FASEB J. 14:312-318.

Benzie IFF, Strain JJ, 1996. The ferric reducing ability of plasma (FRAP) as a measure of "antioxidant power": The FRAP assay. Anal. Biochem. 239:70-76. 
Berra E, Forcella M, Giacchini R, Marziali L, Rossaro B, Parenti $P, 2004$. Evaluation of enzyme biomarkers in freshwater invertebrates from Taro and Ticino river, Italy. Ann. Limnol. - Int. J. Lim. 40:169-180.

Bertrand M. 2010. Carotenoid biosynthesis in diatoms. Photosynthesis Res. 106:89-102.

Brigelius-Flohé R, 1999. Tissue-specific functions of individual glutathione peroxidases. Free Radical Bio. Med. 27:951-965.

Buege JA, Aust SD, 1978. Microsomal lipid peroxidation. Method. Enzymol. 52:302-310.

Buffenstein R, Edrey YH, Yang T, Mele J, 2008. The oxidative stress theory of aging: embattled or invincible? Insights from non-traditional model organisms. Age 30:99-109.

Costantini D, 2014. Oxidative stress and hormesis in evolutionary ecology and physiology: a marriage between mechanistic and evolutionary approaches. Springer, Berlin: 348 pp.

Costantini D, Rowe M, Butler MW, McGraw KJ, 2010. From molecules to living systems: historical and contemporary issues in oxidative stress and antioxidant ecology. Funct. Ecol. 24:950-959.

Dias FA, Gandara ACP, Perdomo HD, Gonçalves RS, Oliveira CR, Oliveira RLL, Citelli M, Polycarpo CR, Santesmasses D, Mariotti M, Guigó R, Braz GR, Missirlis F, Oliveira PL, 2016. Identification of a selenium-dependent glutathione peroxidase in the blood-sucking insect Rhodnius prolixus. Insect Biochem. Mol. Biol. 69:105-114.

Dowling DK, Simmons LW, 2009. Reactive oxygen species as universal constraints in life-history evolution. Proc. R. Soc. B 276:1737-1745.

Duncan DB, 1955. Multiple range and multiple F test. Biometrics 11:1-42.

Erel O, 2004. A novel automated direct measurement method for total antioxidant capacity using a new generation, more stable ABTS radical cation. Clin. Biochem. 37:277-285.

Farooqui T, Farooqui AA (eds.), 2012. Oxidative stress in vertebrates and invertebrates. Molecular aspects of cell signalling. J. Wiley \& Sons, Hoboken: 424 pp.

Flohé L, Günzler WA, 1984. Assay of glutathione peroxidase. Method. Enzymol. 105:115-121.

Gil del Valle L, 2011. Oxidative stress in aging: Theoretical outcomes and clinical evidences in humans. Biomed. Aging Pathol. 1: 1-7.

Grintzalis K, Zisimopoulos D, Grune T, Weber D, Georgiou CD, 2013. Method for the simultaneous determination of free/protein malondialdehyde and lipid/protein hydroperoxides. Free Radical Bio. Med. 59:27-35.

Habig WH, Pabst MJ, Jakoby WB, 1974. Glutathione S-transferases - the first enzymaticstep in mercapturic acid formation. J. Biol. Chem. 249:7130-7139.

Halliwell B, 2007. Biochemistry of oxidative stress. Biochem. Soc. T. 35:1147-1150.

Halliwell B, Gutteridge JMC, 1995. The definition and measurement of antioxidants in biological-systems. Free Radical Bio. Med. 18:125-126.

Harman D, 1956. Aging: a theory based on free radical and radiation chemistry. J. Gerontol. 11:298-300.

Hermes-Lima M, Moreira DC, Rivera-Ingraham G, Giraud-Billoud M, Genaro-Mattos TC, Campos ÉG, 2015. Preparation for oxidative stress under hypoxia and metabolic depression: Revisiting the proposal two decades later. Free Radical Bio. Med. 89:1122-1143.
Hetz SK, Bradley TJ, 2005. Insects breathe discontinuously to avoid oxygen toxicity. Nature 433:516-519.

Huang TT, Carlson EJ, Gillespie AM, Shi Y, Epstein CJ, 2000. Ubiquitous overexpression of CuZn superoxide dismutase does not extend life span in mice. J. Gerontol. Ser. A Biol. Sci. Med. Sci. 55:5-9.

Hulbert AJ, Pamplona R, Buffenstein R, Buttemer WA, 2007. Life and death: Metabolic rate, membrane composition, and life span of animals. Physiol. Rev. 87:1175-1213.

Jena K, Kar PK, Kausar Z, Babu CS, 2013. Effects of temperature on modulation of oxidative stress and antioxidant defenses in testes of tropical tasar silkworm Antheraea mylitta. J. Therm. Biol. 38:199-204.

Kim BY, Kim HJ, Lee KS, Seo SJ, Jin BR, 2007. Catalase from the white-spotted flower chafer, Protaetia brevitarsis: cDNA sequence, expression, and functional characterization. Comp. Biochem. Phys. B 149:183-190.

Ku HH, Brunk UT, Sohal RS, 1993. Relationship between mitochondrial superoxide and hydrogen peroxide production and longevity of mammalian species. Free Radical Bio. Med. 15:621-627.

Lalouette L, Williams CM, Hervant F, Sinclair BJ, Renault D, 2011. Metabolic rate and oxidative stress in insects exposed to low temperature thermal fluctuations. Comp. Biochem. Phys. A 158:229-234.

López-Rodríguez MJ, Tierno de Figueroa JM, Alba-Tercedor J, 2009a. The life history of Serratella ignita (Poda, 1761) (Insecta: Ephemeroptera) in a temporary and permanent Mediterranean stream. Aquat. Sci. 71:179-188.

López-Rodríguez MJ, Tierno de Figueroa JM, Alba-Tercedor J, 2009b. Life history of two burrowing aquatic insects in Southern Europe: Leuctra geniculata (Insecta: Plecoptera) and Ephemera danica (Insecta: Ephemeroptera). Aquat. Insect. 31:99-110.

López-Rodríguez MJ, Tierno de Figueroa JM, Fenoglio S, Bo T, Alba-Tercedor J, 2009c. Life strategies of 3 Perlodidae species (Plecoptera, Insecta) in a Mediterranean seasonal stream of Southern Europe. J. N. Am. Benthol. Soc. 28:611-625.

Martínez-Álvarez RM, Morales AE, Sanz A, 2005. Antioxidant defences in fish: biotic and abiotic factors. Rev. Fish Biol. Fisher. 15:75-88.

Mathews MC, Summers CB, Felton GW, 1997. Ascorbate peroxidase: A novel antioxidant enzyme in insects. Arch. Insect Biochem. Physiol. 34:57-68.

McCord JM, Fridovich JM, 1969. Superoxide dismutase: an enzyme function for Erythrocuprein (Hemocuprein). J. Biol. Chem. 244:6049-6055.

Mockett RJ, Sohal RS, Orr WC, 1999. Over expression of glutathione reductase extends survival in transgenic Drosophila melanogaster under hyperoxia but not in normoxia. FASEB J. 13:1733-1742.

Monaghan P, Metcalfe NB, Torres R, 2009. Oxidative stress as a mediator of life history trade-offs: mechanisms, measurements and interpretation. Ecol lett. 12:75-92.

Montgomery MK, Hulbert AJ, Buttemer WA, 2011. Does the oxidative stress theory of aging explain longevity differences in birds? II. Antioxidant systems and oxidative damage. Exp. Geront. 47:211-222.

Morales AE, García-Rejón L, de la Higuera M, 1990. Influence of handling and/or anaesthesia on stress response in rainbow 
trout. Effects on liver primary metabolism. Comp. Biochem. Physiol. 95A:87-93.

Page MM, Richardson J, Wiens BE, Tiedtke E, Peters CW, Faure PA, Burness G, Stuart JA, 2010. Antioxidant enzyme activities are not broadly correlated with longevity in 14 vertebrate endotherm species. Age 33:33-47.

Paliwal C, Ghosh T, George B, Pancha I, Maurya R, Chokshi K, Ghost A, Mishra S, 2016. Microalgal carotenoids: Potential nutraceutical compounds with chemotaxonomic importance. Algal Research 15:24-31.

Pfenning B, Poethke HJ, 2006. Variability in the life history of the water strider Gerris lacustris (Heteroptera: Gerridae) across small spatial scales. Ecol. Entomol. 31:123-130.

Prior RL, Cao G, 1999. In vivo total antioxidant capacity: comparison of different analytical methods. Free Radical Bio. Med. 27:1173-1181.

Richter CH, Park JW, James BN, 1988. Normal oxidative damage to mitochondrial and nuclear DNA is extensive. P. Natl. Acad. Sci. USA 85:6465-6467.

Sanz A, Trenzado CE, Castro Botello H, López-Rodríguez MJ, Tierno de Figueroa JM, 2013. Relationship between brain and liver oxidative state and maximum lifespan potential of different fish species. Comp. Biochem. Phys. A 165:358-364.

Sanz A, Trenzado CE, López-Rodríguez MJ, Furné M, Tierno de Figueroa JM, 2010. Study of the antioxidant defences in four species of Perloidea (Insecta, Plecoptera). Zool. Sci. 27:952-958.

Sanz A, Trenzado CE, López-Rodríguez MJ, Tierno de Figueroa JM, 2014. Physiological strategies contributing to the coex- istence of two predatory species of stoneflies: Dinocras cephalotes (Curtis 1827) and Perla bipunctata Pictet, 1833. Comp. Biochem. Phys. A 175:131-134.

Sies H, 1997. Oxidative stress: oxidants and antioxidants. Exp. Physiol. 82:291-295.

Sohal RS, Sohal BH, Brunk UT, 1990. Relationship between antioxidant defences and longevity in different mammalian species. Mec. Ageing Dev. 53:217-227.

Storey KB, Storey JM, 2010. Oxygen: stress and adaptation in cold hardy insects, p. 141-165. In: D.L. Delinger and R.E. Lee (eds.), Low temperature biology of insects. Cambridge University Press, Cambridge.

Sturve J, Stephensen E, Forlin L, 2005. Effects of redox cycling compounds on DT diaphorase activity in the liver of rainbow trout (Oncorhynchus mykiss). Comp. Hepat. 4:4.

Tachet H, Richoux P, Bournaud M, Usseglio-Polatera P, 2010. [Invertébrés d'eau douce. Systématique, biologie, écologie].[Book in French]. CNRS Editions, Paris: 607 pp.

Tierno de Figueroa JM, Sánchez-Ortega A, Membiela-Iglesia P, Luzón-Ortega JM, 2003. Plecoptera. In: M.A. Ramos et al. (eds.), Fauna Ibérica. Museo Nacional de Ciencias Naturales, CSIC, Madrid.

Tierno de Figueroa JM, López-Rodríguez MJ, Peralta-Maraver I, Fochetti R, 2015. Life cycle, nymphal feeding and secondary production of Dinocras cephalotes (Plecoptera) in a Mediterranean river. Ann. Soc. Entomol. Fr. 51:259-265.

Tolmasoff JM, Ono T, Cutler RG, 1980. Superoxide dismutase: Correlation with life-span and specific metabolic rate in primate species. P. Natl. Acad. Sci. USA 77:2777-2781. 